at its best, while his paper on "The Vegetation of Upper Teesdale", published in 1956, discloses field studies in their most impressive and rewarding form. In $1960 \mathrm{Dr}$. Pigott returned to a lectureship in Cambridge, where he has continued to pursue direct research on the relationship between the plant and the soil environment with particular emphasis on the phosphate requirements of woodland species sensitive to low concentrations of this element. Dr. Pigott's field studies in the Pennines have led him to important conclusions regarding the origin of the soils of that region as affected by the conditions of the glacial and post-glacial periods, and together with his wife he has published interesting investigations of pollen analysis of the vegetational history of the Malham area. Dr. Pigott will bring to Lancaster much experience of, and an alert interest in, soils, vegetation and the general ecology of Northern England.

\section{The 1962 Corday-Morgan Medal and Prize}

Dr. N. BARTLETT, associate professor in the Department of Chemistry, University of British Columbia, has been awarded the 1962 Corday-Morgan Medal and Prize by the Chemical Society in consideration of his prediction and discovery of the first stable compounds of an inert gas. This award, consisting of a Silver Medal and a monetary prize, is made annually to the chemist of either sex and of British nationality who, in the judgment of the Council of the Chemical Society, has published during the year in question, and in the immediately preceding five years, the most meritorious contribution to experimental chemistry, and who has not, at the date of publication, attained the age of thirty-six years.

Effective Use of Technical College Resources in Britain

The National Advisory Council on Education for Industry and Commerce is to set up a new committee to suggest ways of making the most effective use of technical college resources. The terms of reference of the committee will be: "In the light of the expansion of their work now in hand, and the further demands which national developments are likely to place on them, to suggest ways of making the most effective use of the resources available and expected to become available in technical and other colleges of further education". Sir Harry Pilkington, chairman of the National Advisory Council on Education for Industry and Commerce, is to be chairman of the committee, which will include: Sir William Alexander, secretary of the Association of Education Committees; Dr. Frank Briers, principal of the City College and Art School, Norwich; Mr. J. A. Hunt, director, Hymatic Engineering Co., Ltd., and chairman of Governing Body, Birmingham College of Advanced Technology; Mr. J. Longden, head of Mechanical Engineering Department, Mid-Warwickshire College of Further Education, and at present president of the Association of Teachers in Tochnical Institutions; $\mathrm{Mr}$. S. J. Noel-Brown, chairman and managing director, S. J. Noel-Brown and Co., Ltd., management consultants; Dr. F. Lincoln Ralphs, chief education officer, Norfolk County Council; Sir Lionel Russell, chief education officer, Birmingham.

\section{Desalination of Salt Water}

Is reply to a question in the House of Lords on March 3, the Parliamentary Secretary to the Minister for Science, the Earl of Bessborough, said that the Government had noted the announcement of the President of the United States on February 6 of co-operation with Israel in research into ways of turning salt water into fresh by means of nuclear energy, and of their willingness to pool intellectual resources working on this problem with all countries. An expert from the British Water Research Association recently visited Israel and was fully conversant with what was being done there. The United
Kingdom was represented by two leading experts on a panel convened by the International Atomic Energy Agency, the focal point for probing experience and knowledge, and Britain would continue to contribute the benefits of her knowledge and experience. So far, distillation processes were the only methods of desalination capable of economic application and they were used in installations built by British firms, which were recognized throughout the world as the leading manufacturers and had been responsible for the bulk of the installations at present operating overseas. The Department of Scientific and Industrial Research had set up a committee to con. sider what further help could be provided to support research in British industry to help the United Kingdom in the forefront of desalinating technology. In principle there was no difficulty in using nuclear energy as the source of heat, and in some circumstances combinations of a distillation plant with a power station could offer advantage. The Atomic Energy Authority was studying these problems.

Later, the Earl of Bessborough put the cost of water supplied by this method in Britain at about 9s. per 1,000 gallons and added that Britain used only about 5 per cent of her rainwater as opposed to 95 per cent in Israel. He declined to discuss the question of underground storage and could give no estimate of the cost of the research work on the use of nuclear power for this purpose. Afterwards, he announced that the Council for Scientific and Industrial Research had offered an earmarked grant of $£ 34,325$ over three years to the Water Research Association for investigations in desalination, which would enable the Association to keep a closer watch on work in the United States and elsewhere and to commission a study of the economic factors as they affect Britain. (See also p. 1 of this issue of Nature.)

\section{Water Supply, Drainage and Pollution}

Arso on March 3, the Earl of Albemarle asked the Government to arrange for interdepartmental consultation forthwith between the Waterways Board and the Housing, Agricultural and Health Departments so as to adjust future policy regarding water supply, drainage and pollution; and put to common use the maps and graphs accumulated by the Surface Water Inland Survey Division. Replying, the Joint Parliamentary Secretary to the Ministry of Housing and Local Government, Lord Hastings, said that consultation was possible without special arrangements and much of the information held by the Surface Water Survey of the Ministry of Housing and Local Government had been published. There had also been full exchange of information of mutual interest between the Survey and the Waterways Board and its predecessors. The Earl of Albemarle pointed out that the Board had complained in its interim report of difficulties over consultation and he also pointed out that insufficient attention was being directed to the purity of water. Much of the $£ 595,000$ received by the Waterways Board was from sales of water to factories on the banks of canals which did not want pure water; he urged that more attention should be directed to the use of unpurified water from the canals. Supported by Earl Alexander of Hillsborough and Viscount St. Davids, the Earl of Albemarle pressed his request for urgent attention to the matter of consultation, and finally Lord Hastings agreed to take the matter to the Minister.

\section{Extra-mural Work and Audio-visual Aids}

IN a written answer in the House of Commons on March 3, the Minister for Science, Mr. Q. Hogg, stated that in the academic year 1961-62 universities spent $£ 468,000$ from their general income on extra-mural classes and similar work. Grants to extra-mural departments of universities by the Ministry of Education were $£ 555,000$ in the financial year 1962-63 and were expected to total 